\title{
Diction Associative Meaning: The Case of Men and Women Face Wash Products in Indonesia
}

\author{
Riri Rachmah Riani, Didin Nuruddin Hidayat, and Alek Alek \\ Universitas Islam Negeri Syarif Hidayatullah, Tangerang Selatan, Indonesia \\ riri_riani19@mhs.uinjkt.ac.id
}

\begin{abstract}
ARTICLE HISTORY
Received : 16 February 2021

Revised : 13 March 2021

Accepted : 19 May 2021
\end{abstract}

\section{KEYWORDS}

Diction
Semantics
Associative Meaning
Face Wash Products
Gender

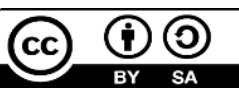

\begin{abstract}
Previous studies often analysed the advertisements of products, but seldom focused on the packaging. This research compares the associative meaning of English and Indonesian dictions in face wash products for men and women. The descriptions of 60 face wash products (i.e., 30 men and 30 women products from Watson, Century, Guardian, and other beauty stores) were collected in November 2020. This research used semantic analysis to discover the associative meanings which occur in the dictions and to find out whether they correspond with the consumer's point of view. Results showed that from the five associative meanings (i.e., connotative, reflected, social, affective, and collocative), both gender-targeted products use dictions of reflection meaning. A novelty of this study is the thorough analysis of the two most common English and Indonesian terms used in face wash products, namely white (e.g., Flawless White and White Perfect, White Beauty, Sakura White, Rosy White, Pearly White, Sparkling White, White Energy, Power White, Healthy White) and bright (e.g., Glowing Bright, Natural Bright, Active Bright, Energy Bright, Healthy Bright). Dictions of women's products primarily give an impression of beauty for the female facial skin (e.g., lovely, sparkling, flawless, and pearly), whereas dictions for men's products give an impression of strengths (e.g., fighter, buster, energy, and active). This leads to the conclusion that the dictions in face wash products for women are related to ideal physical characteristics of female skin. As for men's products, the dictions are related to general characteristics of being an active man.
\end{abstract}

\section{Introduction}

Health and body shops in Indonesia, such as Guardian, Watson, Dan-Dan, Century, and other stores, arrange women's products either according to their use or based on product brands. Based on the researchers' observation, these store arrangements or distribution of beauty and face care products are dominated by products for women with many kinds of variation. On the other hand, men's products are not as varied as women's products.

In the Critical Discourse Analysis approach, Fairclough (1993) and Hwai (2018) stated that language use is influenced by social identity, social relations, social knowledge, or belief. In this case, the text advertisement in beauty and facial care products needs to deal with customers' problems by looking at discourses in society related to men or women. The choice of diction for male and female care and beauty products affects and influences buyers' decision. As stated by Pilatova (2015) and Brook et al. (2020), advertisements appear in every place and have power to persuade customers by using unique words. In line with this, Wulandari (2017) and Alwasilah (1983) stated that associative meaning is the same as the symbol or symbol used by the language community to express other concepts which are similar to the properties, conditions, or features that exist in the concept of the origin of the word or lexeme.
Furthermore, Lakoff (1975) did a study on language and gender issues. He found the differences between men and women language used. In his research, women tend to use more colorful words to describe something rather than men. Also, Eisend (2019) and Yananingtyas (2018) stated that gender differences inreal life lead to things depicted in advertisements. With the development of times, stereotypes related to men and women are slowly starting to change. In advertisements, the text deals with customers' problems first, including their needs and desire. The text is also rich in meaning. Different advertisement companies will use different strategic and communicative actions to attract consumers' attention. In this case, cosmetic companies ytry to sell their products by trying to follow this phenomenon. Besides the diction selections for men and women, the selection of words also became neutral for both in several contexts. There are several overviews of word's selection in face wash products, such as 'active', 'cool', 'soft', 'smooth', and others. Based on the case above, several face wash products do not specify word selection for women and men. The choice of words on women's face wash can also be used in men's products and vice versa.

In addition, beauty and facial care products vary in terms of usage. Judging from its usefulness, the researchers will focus on choosing a diction for face wash products or facial cleansing soap because washing the face is a daily activity 
usually done by people around the world, especially in the worldwide pandemic. Due to the COVID-19 pandemic, World Health Organization/WHO (Cucinotta \& Vanelli, 2020) made it mandatory for people to wash their hands and use a mask to prevent the viruses. Therefore, people need to take care of their hygiene behaviors. This research only focuses on Indonesian people because the researchers are familiar with the Indonesian context. Since the pandemic is currently happening, Indonesians followed WHO command to wear a mask in everyday life. That is why cleaning the face is the same thing as washing the body or taking a shower; it becomes necessary.

Based on the explanation above, the researchers are interested in discussing face wash product descriptions. The uniqueness in this research is the focus of the research itself. Most researchers have focused on electronic or printing advertisements rather than the packaging, while this research will focus on the diction contained on the male and female face wash packaging. Another novelty of this research is the comparison of how beauty products and facial care products differentiate between men and women in terms of the diction displayed on face wash products.

This research aims to discover the associative meanings in the dictions and determine whether they correspond with the consumers' point of view. For this purpose, two research questions were formulated: (1) What are the dictions use on the face wash products for males and females?; and (2) What are associative meanings contained in the diction of face wash products?

\section{Literature Review}

Keraf (2010) stated that diction means choosing and composing words in speech or writing. Diction is the choice of words that are right and in harmony (in use) to express ideas so that certain effects are obtained. Further, Lyons (1995) explained that some language expressions, both spoken and written, depend on the listener's interpretation and the context in which these expressions appear. Context is influenced by the speaker's and listener's beliefs and culture.

According to Abdul (2012), associative meaning is a symbol used by a language community to express other concepts which have similarities with the properties, circumstances, or features that exist in the concept of the origin of the word or lexeme. There are five associative meanings according to Leech's theory (1990), as follows:

a. Connotative Meaning: The communicative value possessed by an expression and has its own concept.

b. Social Meaning: An expression that can indicate the state of the user's social environment in using the expressions.

c. Affective Meaning: The meaning that expresses the speaker's feelings and shows the speaker's true emotions. The affective meaning in a sentence also involves the responses and impressions of the listener. This affective meaning depends on the choice of words used in a sentence.

d. Reflected Meaning: The meaning appears in a dual conceptual meaning when the meaning (senses) of a word creates a response in the form of another meaning.

e. Collocative Meaning: The meaning contains the associations in a word that tends to appear in its environment.

Regarding the case of diction associative meaning in face wash products for men and women, there are some previous studies related to our research. Authar's (2018) study discussed the choice of words or diction in the form of printed advertisements that target both male and female readers. He established that printed advertisements are advertisements related to stereotypical gender interests with stereotypical word choices. He found the relationship between gender and diction in the printed advertisement: the word of 'White Super Fresh' continued by 'Maybe She's Born with It. Maybe It's Maybelline' has attractiveness from the customer's point of view. He stated that it would make the customers feel fresh all the time, and the customers who use this product will always be happy. Therefore, the combination of words and meaning is one strategy used by the advertiser to make the customers buy the product. Additionally, this study's findings showed that diction and gender have been integrated and can convince the consumers to buy the products based on the use of gender-related language used in the advertisement.

In addition, a study in Indonesia's poetry language discussed the differences about words selection for men and women. Hwai (2018), examined the diction of men and women in Indonesian Mutahir Poetry. This research explained gender, which is one factor that influences the choice of language or diction, especially in poetry. He found that the Indonesian nation has a dichotomy in language selection where there are differences in the language used by men or women. He highlighted that women used stronger (more emphatic) adjectives more often than men. For example, women used 'adorable', 'charming', 'sweet', or 'lovely', more often than neutral words like 'great', 'terrific', 'cool', or 'neat'.

Focusing on the use of language in advertisements, Yananingtyas (2018) undertook a qualitative functional semantic analysis on Nivea's printed advertisements. The researcher applied Leech's theory to analyze the data. They found that there were different types of meaning in Nivea's printed advertisements, i.e., connotative meaning (44\%), affective meaning (29\%), reflected meaning (3\%), collocative meaning (18\%), and stylistic meaning (3\%).

Based on previous studies as presented above, our study shares some similarities with them, but it also brings a new perspective to the study of the topic.. The similarities lie in the fact that our research analyzes the differences in the words used in products for men and women. The novelty of 
this research lies in the focus of the research itself. Most researchers focused on electronic or printing advertisement rather than the packaging, while this research will focus on the diction contained on the male and female face wash product packaging.

\section{Method}

The main data in this study came from descriptive texts on face wash product packaging soled in several specialty beauty product stores (e.g., Watson, Century, Guardian, and other stores). Data collection were collected in November 2020. From a vast range of $\mathrm{s}$ facial cleansing products that are sold in stores, researchers selected 60 face wash product descriptions, consisting of 30 male products and 30 female products, to be studied based on the the language used in them. The researchers considered products which use English or a mixture of Indonesian and English as the data and eliminated products that use languages other than those two, such as Chinese, Japanese or Korean. Leech (1990) theorized five associative meanings: collocative meaning, reflection meaning, connotative meaning, social meaning, and affective meaning. Nonetheless, in the present study, the researchers only used the first three meaning.

\section{Results \& Discussion}

To display the findings of this research, the researchers tabulated the diction data on men and women face wash in the form of adjectives and verbs, as follows:

Table 1. Classification of Dictions in the Face Wash Products

This table only showed three associative meaning, such as collocative, reflected, and connotative meaning.

\begin{tabular}{|c|c|c|c|c|c|c|c|c|}
\hline \multicolumn{9}{|c|}{ Associative Meaning } \\
\hline & \multicolumn{2}{|c|}{ Neutral } & \multicolumn{2}{|c|}{ Collocative } & \multicolumn{2}{|c|}{ Reflected } & \multicolumn{2}{|c|}{ Connotative } \\
\hline & Women & Men & Women & Men & Women & Men & Women & Men \\
\hline 1. & Sehat & Sehat & None & None & None & None & None & None \\
\hline 2. & $\begin{array}{l}\text { Healthy, } \\
\text { Healthy Glow }\end{array}$ & Healthy White & None & None & None & None & None & None \\
\hline 3. & None & None & Lembut & None & None & None & None & None \\
\hline 4. & $\begin{array}{l}\text { Halus, Halus } \\
\text { Bercahaya }\end{array}$ & Halus & None & None & None & None & None & None \\
\hline 5. & $\begin{array}{l}\text { Soft, } \\
\text { Beautifully Soft }\end{array}$ & Softer & None & None & None & None & None & None \\
\hline 6. & Smooth & Smooth, Smoother & None & None & None & None & None & None \\
\hline 7. & None & None & Bening & None & None & None & None & None \\
\hline 8. & None & None & Kenyal & None & None & None & None & None \\
\hline 9. & Bersih & Bersih & None & None & None & None & None & None \\
\hline 10. & $\begin{array}{l}\text { Clear, Super } \\
\text { Clear }\end{array}$ & Clearer, Perfect Clear & None & None & None & None & None & None \\
\hline 11. & $\begin{array}{l}\text { Clean, Super } \\
\text { Clean }\end{array}$ & $\begin{array}{l}\text { Clean, Perfectly } \\
\text { Clean, Perfectly } \\
\text { Cleansed, Pleasant } \\
\text { Clean, Overall Clean }\end{array}$ & None & None & None & None & None & None \\
\hline 12. & $\begin{array}{l}\text { Fresh, } \\
\text { Refreshed }\end{array}$ & Refresh, Refreshing & None & None & None & None & None & None \\
\hline 13. & None & None & None & Segar & None & None & None & None \\
\hline 14. & None & None & None & None & $\begin{array}{l}\text { Cerah, Cerah Merona, } \\
\text { Rona Sehat }\end{array}$ & Cerah & None & None \\
\hline 15. & None & None & None & None & $\begin{array}{l}\text { Bright, Natural Bright, } \\
\text { Super Bright }\end{array}$ & $\begin{array}{l}\text { Bright, Brighter, Cool, } \\
\text { Brightening, } \\
\text { Brightened, Active } \\
\text { Bright }\end{array}$ & None & None \\
\hline 16. & None & None & Bercahaya & None & None & None & None & None \\
\hline 17. & None & None & None & None & $\begin{array}{l}\text { Glows, Glowing, } \\
\text { Glowing Bright, } \\
\text { Natural Glow, Healthy } \\
\text { Glow }\end{array}$ & None & None & None \\
\hline 18. & None & None & None & None & $\begin{array}{l}\text { Radiant, Pinkish } \\
\text { Radiant }\end{array}$ & None & None & None \\
\hline 19. & None & None & Cantik & None & None & None & None & None \\
\hline 20. & None & None & None & None & None & None & Pure & None \\
\hline 21. & None & None & Fair & Fairer & None & None & None & None \\
\hline 22. & Energized & Energized & None & None & None & None & None & None \\
\hline
\end{tabular}




\begin{tabular}{|c|c|c|c|c|c|c|c|c|}
\hline 23. & None & None & None & None & Putih & None & None & None \\
\hline 24. & None & None & None & None & $\begin{array}{l}\text { White beauty, White } \\
\text { Perfect, Sparkling } \\
\text { White, Pearly White, } \\
\text { Rosy White }\end{array}$ & $\begin{array}{l}\text { White Energy, White } \\
\text { Power }\end{array}$ & None & None \\
\hline 25. & None & None & None & None & Matte & None & None & None \\
\hline 26. & None & None & None & None & Spotless & None & None & None \\
\hline 27. & None & None & None & None & Lovely & None & None & None \\
\hline 28. & None & None & None & Mild & None & None & None & None \\
\hline 29. & None & None & None & Gentle & None & None & None & None \\
\hline 30. & None & None & None & Silky & None & None & None & None \\
\hline 31. & None & None & Balanced & None & None & None & None & None \\
\hline 32. & None & None & Translucent & None & None & None & None & None \\
\hline 33. & None & None & Refined & None & None & None & None & None \\
\hline 34. & None & None & None & None & None & None & None & Buster \\
\hline 35. & None & None & None & None & None & None & None & Fighter \\
\hline 36. & None & None & None & None & None & None & None & Attack \\
\hline 37. & None & None & None & None & None & None & None & Control \\
\hline 38. & None & None & None & None & None & None & Moisture & None \\
\hline Total & & 16 & \multicolumn{2}{|l|}{10} & \multicolumn{2}{|c|}{28} & \multicolumn{2}{|c|}{6} \\
\hline & & $9.6 \%$ & \multicolumn{2}{|c|}{$6 \%$} & \multicolumn{2}{|c|}{$16.8 \%$} & \multicolumn{2}{|c|}{$3.6 \%$} \\
\hline
\end{tabular}

Based on the table above, it can be concluded that the highest percentage of words is found in the reflected associative meaning category $(16.8 \%)$. This result is related to the previous explanation that diction words chosen for men's and women's products are different. It is based on the characters and associations related to men's and women's needs.

\subsection{Diction Associative Meaning in Face Wash}

\subsubsection{The Diction of Collocative Meaning on Face Wash Product Descriptions}

Faizah (2017) and Saeed (2003) stated that collocative meaning relates to certain characteristics of meaning which a word has compared to several synonymous words. The word is only suitable for use in combination with certain other words. Hence, the collocative meaning must be proportional and appropriate. The word choices on men's and women's face wash product packaging are made differently by the manufacturers. The aim is to attract consumers by writing a diction related to product characteristics and associating them with consumers, i.e. men and women. In addition, diction can be called a neutral word when it is found in both men's and women's face wash product descriptions, for example, clean, healthy, bright, etc. Based on Table 1, the researchers can conclude that most of the diction that describes men's faces can also be found in face wash product descriptions for women, such as the word 'energized'.
In contrast to this finding, many dictions found in women's face wash product descriptions were not found in male face wash product descriptions, such as 'beauty', 'sparkling', and others. In the diction listed on the face wash descsription, we found collocative meanings to the words on product packaging. As explained in the previous section, collocative meaning is a meaning that tends to appear in the environment or a word that has limitations in usage. In line with this, Leech (1990) and Authar (2018) stated that the word of beauty is also found in their collocative meaning analysis. For example, one face wash product description for female consumers uses the word 'beautifully soft' and the word 'beautiful,' which are commonly used to describe women. The diction that describes a blushing face, such as 'Pearly White, Rosy White and Sakura White,' is not found on men's face wash product description because white skin that blushes pink tends to be associated with women's faces only.

Further, figurative language includes the structural elements of literary works. Language functions can animate sentences and provide space for sentences and cause specific reactions that can lead to readers' thoughts and responses (Dewi et al., 2020; Lyons, 1995; Pradopo, 2019). Hyperbole and diction that showed lights are also only found in women's face wash product descriptions, e.g. the words of Glowing, Sparkling White, and so on. One description (i.e. sample no. 26) even uses the word choice 'Fair and Lovely' as their brand name, which are familiar words associated with women. 


\subsubsection{The Diction of Reflection Meaning on Face Wash Product Descriptions}

The diction on face wash products packaging also contains a meaning of reflection: the meaning seen in a phrase that involves two words with two other concepts but still related to one another. The concept is related to men's and women's characteristics and associations. Plume and Slade (2018) stated that advertisements become a part of people's everyday life to convey certain messages about the products and persuade customers to buy the products. Coulmas (2018) stated that men and women choose different vocabulary because naturally, they are different. In line with this, men's and women's language are different in nature (Biber \& Burges, 2000; Pease \& Pease, 2004). Coates (1986) also stated that differences in the language of men and women are also caused by culture, which is closely related to social attitudes and differences that start from birth. For instance, Stevenson et al. (2019) provided an example that diet is a word that is often identified with women because the diet is done to look slimmer, which is considered a symbol of beauty. Setiawati (2018) and Palmer (1976) stated that women use words that have complex denotation. According to Kristi (2019), women prefer to use gentle, beautiful, motherly, and emotional words. Meanwhile, men are considered strong, rational, manly, and mighty.

Here are several examples of reflective meaning on face wash packaging, as follows:

\section{a. White}

The word 'white' on face wash product packaging describes the use and results consumers will get after using the product. The meaning of the word 'white' in the (Oxford, n.d.) dictionary is 'of the color of milk or fresh snow, the opposite of black'. The word 'white' describes a consumer's skin that will turn white after using the product. In line with this, Prabasmoro (2017) and Yulianto (2017) explained a very close relationship between 'white' discourse that is currently very prevalent in Asian countries and their 'fascination' for the white race. According to Prabasmoro (2017) and Yulianto (2017), Asian people's fascination with whiter skin cannot be separated from Indonesia's history as a colony. McLeod (2000) also said that other white nations are conceptualized as others or 'Sang Liyan', which shows the lower people because the high people have white skin. In addition, to make it interesting, the manufacturer added another word to make it a phrase.

\section{1) Flawless White and White Perfect}

In data 22, the word 'white' is juxtaposed with the word 'flawless'. Besides, samples 29 and 30 used the word 'perfect'. The word 'flawless' means without any blemishes or imperfections; perfect. Further, the words flawless and perfect have the same meaning and when juxtaposed with the word white. The word 'flawless' means 'perfect white skin without blemishes or blemishes', and the word 'perfect' becomes 'perfect white skin'. In line with this, the word white itself carries the meaning of clean, which is quoted from KBBI, which means free from dirt, and it refers to the word flawless.

\section{2) White Beauty}

In samples 22 and 24, the word 'white' is juxtaposed with the word 'beauty'. The word beauty means a combination of qualities, such as shape, color, or form that pleases the aesthetic senses, especially the sight. The word 'white' shows the reflection meaning of beauty, which implies that 'white' means 'beautiful,' or by giving consumers white skin, it means that the consumer will become beautiful.

\section{3) Sakura White}

In sample 18, the word 'white' is juxtaposed with the word 'Sakura'. The literal meaning of Sakura White based on the data is white (like) cherry blossoms. Cherry blossoms are used as a metaphor to describe the ideal skin tone for women.

Based on the data obtained from the original data website, the product model tries to show the similarity of the color tone of the face and the cherry blossoms. The cherry blossoms themselves are identified as white and pinkish flowers, which is the skin condition in the product promises (white skin with a pinkish hue on the cheeks).

\section{4) Rosy White}

In data 24, the word 'white' is juxtaposed with the word 'rosy' and created a phrase of Rosy White. The word 'rosy' comes from the word rose and usually describes a pinkish or rose, like the pinkish color on someone's cheeks.

Furthermore, it is different from the previous one that used cherry blossoms. This product used the word of rosy white and made the rose become a metaphor to describe women's ideal face. The word 'white' brings out the reflection meaning of rosy, representing a beautiful woman's face with white skin and pink blush on their cheeks.

\section{5) Pearly White}

In sample 27, the word 'white' is juxtaposed with the word 'pearly', which comes from the word 'pearl'. The word 'white' shows the meaning of pearly reflection to illustrate how white the product will give to consumers' skin. Contrary to Sakura White and Rosy White, who use flowers to describe ideal skin, data 27 used pearls as a metaphor. The phrase Pearly White can be interpreted as white (which is like) pearl.

\section{6) Sparkling White}

In sample 28, the word 'white' is juxtaposed with the word 'sparkling'. The word sparkling has the Indonesian meaning berkilau or, in the (Oxford, n.d.) dictionary shining brightly with flashes of light. The word 'sparkling' is usually used to describe something luminous and shiny. The meaning contained in the word sparkling is poetic, where when the word 'sparkling' is used to describe a woman's face, even the face does not emit the light. It is also different when the word 'sparkling' is used to describe lights in a 
lamp, which are the objects that emit the light. In line with this, Lakoff (1975) stated that women tend to use more colorful words in their narrative and have their vocabulary to describe something. The emergence of sparkling refers to a reflection meaning for the word white. Therefore, the expression of Sparkling White will have the meaning of shining white (putih bersinar).

\section{7) White Energy}

In data 36, the word 'white' is juxtaposed with the word 'energy'. Quoted from the (Oxford, n.d.) dictionary, the word 'energy' means the strength and vitality required for sustained physical or mental activity. We cannot identify a person's appearance with their energetic face. Therefore, the researcher assumes that the word 'energy' relates to a man expected to have energy or strength. White Energy is interpreted as the appearance of a man who has a white and fresh face, giving a strong impression on his face.

\section{8) Power White}

In sample 51, the word 'white' is juxtaposed with the word 'power', which means the capacity or ability to direct or influence others' behavior or the course of events. The emergence of the word 'power' is influenced by the stereotype that men are attracted to things linked to strength and power. As a previous statement, face wash products try to provide as familiar and attractive as possible to attract consumers, especially products that are not unisex.

\section{9) Healthy White}

In sample 57, the word 'white' is juxtaposed with the word 'healthy'. The word 'healthy' appears as a reflection meaning of the word 'white' and becomes the phrase Healthy White. It describes the face of a person who is not only white but looks healthy. Therefore, the word 'healthy' in Healthy White means that the skin produced by these products will have healthy white skin and not pale.

\section{b. Bright}

The word 'bright' on a face wash product packaging describes the use and results that consumers will get after using it. The word 'bright' as quoted from (Oxford, n.d.) dictionary gives out or reflects a lot of light; shining. In addition, to make it attractive, each men's and women's product has its characteristics, so the manufacturer adds one more word to make it as a phrase.

\section{1) Glowing Bright}

In sample 5, the word 'bright' is juxtaposed with the word 'glowing'. As quoted from (Oxford, n.d.) dictionary, 'glowing' have an intense color and a slight shine. Judging from its meaning, the word glowing is related to ray or light. The appearance expression of glowing is as a reflection meaning from the word 'bright'. The word of Glowing Bright refers to hyperbole impression in describing someone's appearance. This is also due to word 'glowing', which is still related to word 'bright' which both words can describe as 'light'.

\section{2) Natural Bright}

In sample 10, the word 'bright' is juxtaposed with the word 'natural'. The word 'natural' comes from the word 'nature'. Meanwhile, the natural word that is quoted from the (Oxford, n.d.) dictionary means existing in or caused by nature, not made or caused by humankind. Further, the word bright can bring out the word natural as a meaning of reflection because it is expected to naturally restore a person's skin color.

\section{3) Active Bright}

In sample 55, the word 'bright' is juxtaposed with the word 'active,' which is defined as engaging or ready to engage in physically energetic pursuit. Active Bright means are bright and active. The word active in these products is probably related to familiar things to consumers, which is in men's products. Men are expected to be active, especially in their outdoor activities. The word 'active' in this phrase means that men who have outdoor activities are exposed to sunlight daily but still have bright skin.

\section{4) Energy Bright}

In sample 36, the word 'bright' is juxtaposed with the word 'energy'. This word is the same as the previous language phenomenon in data 36, in which 'White Energy' is interpreted as a man form who has a white and fresh face so that it gives a strong impression on the consumer's face. Therefore, Energy Bright also has the same meaning considering that the word 'energy' is the meaning of reflection. The word 'white' and 'bright' also talk about the skin tones of a person's face.

\section{5) Healthy Bright}

In sample 57, the word 'bright' is juxtaposed with the word 'healthy'. This case is also similar to Healthy White in sample 57, where Healthy Bright can be interpreted as a man image expected to have a bright, healthy face and not pale.

\subsubsection{The Diction of Connotative Meaning on Face Wash Product Descriptions}

Based on Leech's theory (1990) as described previously, the connotative meaning is the communicative value possessed by an expression and has its concept. The connotative meaning includes the physical, psychological, and social characteristics of a word. This is inversely proportional to the conceptual meaning which interprets a word as it is. Further, to attract consumers' attention in choosing diction on face wash product descriptions, manufacturers need to adjust it by looking at who the consumer is. The diction on men's and women's face wash product descriptions are differentiated. This causes the emergence of connotative meanings in diction: physical, psychological, and social characteristics owned by diction associated with men or women.

Diction on men's face wash products uses neutral words such as words 'clean, clear, remove and others'. Besides, the word 'buster' is used to accompany the word 'oil'. 
Therefore, in the face wash product description for male consumers, the manufacturer uses words associated with men's characteristics. As quoted from the (Oxford, n.d.) dictionary, 'buster' has the literal meaning of a person or thing that breaks, destroys, or overpowers something. Looking at its literal meaning, the word 'buster' gives a harsher, more aggressive impression, and it is not as neutral as commonly used words, such as 'clean' or 'clear'. The word 'buster' can be associated with men because men can bring up the word 'buster' as a connotative meaning.

In addition, the word 'fight' or 'fighter' is used to accompany the words 'oil', 'acne', and others. The word fight is interpreted as taking part in a violent struggle involving physical blows or weapons. The word fight tends to be synonymous with man characteristics, considering that the word 'fight' involves physical activity, which refers to men. This face wash product uses the word fight to give an aggressive impression in the product description. Therefore, this is what affects the word 'fight' as the connotative meaning for the men.

Another example is the word 'attack,' juxtaposed with the word oil in data 60 . It has the same impression as the previous word fight, where the word attack also involves physical strength as its literal meaning. Quoted from the (Oxford, n.d.) dictionary, 'attack' means take aggressive action against (a place or enemy forces) with weapons or armed force, typically in a battle or war. The word 'fight' can appear as a connotative meaning with the word 'man' because things related to resistance, weapons, and warfare are synonymous with men.

Furthermore, the word 'control' is not only found in men's face wash, but also in products for women. However, the number found was different. The word 'control' appeared seven times in men's face wash product descriptions and twice 'in descriptions of products directed at women. 'Control' has a literal meaning as the power to influence or direct people's behavior or the course of events. Based on the meaning, the word 'control' is synonymous with a power related to men's characteristics.

The clinche though, the connotative dictions for women's products are not as varied as the men's as this study found that they always hinge on one certain physical appearance. The word 'beauty' in sample 12 is combined with the words 'moisture' and 'serum' which eventually forms the phrase 'beauty moisture' and 'beauty serum'. The word 'beauty' is only a compliment, which is a characteristic of women. Gender of women can bring up the word 'beauty' as a connotative meaning. This finding points that connotative meaning in women's products are much simpler than men's products. To illustrate the connotative gender of women, this study only found the word 'beauty', not as much as the word formations in men's products.

\section{Conclusion}

Face wash product advertisements differentiate the diction choice in men's and women's products. They use the diction choice according to the character of their target consumers. The diction in men's products leaves a strong impression. In products for men, diction is associated with an active male's character, such as strength, energy, and other men's characters. On the other hand, in women's product descriptions, the dictions leave the impression of beauty and ideal physical characteristics of female skin. The diction is also associated with beauty, where the word of beauty can attract the attention of women. It can be seen that the use of diction on face wash products for women looks more colorful and poetic, which is in line with Lakoff's (1975) statement that women tend to use more colorful words in their speech, and women like to have their vocabulary in describing something. Above all, this language phenomenon was found because the primary purpose of using the word diction on face wash products is to attract target consumers' interest based on gender needs. some limitations were present in this study; the deeper validity analysis is expected to be done in the future, so it can be more apparent to the readers to use the study as the guideline to do the next research. For the next researchers, this study suggests examining the discourse analysis of other language used in advertisements, whether on beauty care products or other products.

\section{References}

Abdul, C. (2012). Linguistik umum. Rineka Cipta.

Alwasilah, A. C. (1983). Linguistik: Suatu pengantar. Penerbit Angkasa.

Authar, N. (2018). The influence of gender and diction in advertisements: Discourse analysis. International Conference on Technopreneurship and Education.

Biber, D., \& Burges, J. (2000). Historical change in the language use of women and men. Journal of English Linguistics, 28(1), 21-37.

Brook, M. E., Clay M., C., \& Bichard, S. (2020). Exploring Ads of the World: How Social Issues Are Framed in Global Advertisements. Howard Journal of Communication, 31(2), 150-170.

Coates, J. (1986). Women, men and language: A sociolinguistic account of sex differences in language. Longman.

Coulmas, F. (2018). The Study of Speakers' Choices. https://assets.cambridge.org/97811070/37649/frontma tter/9781107037649_frontmatter.pdf

Dewi, E. N. F., Hidayat, D. N., \& Alek, A. (2020). Investigating figurative language in "Lose you to love me" song lyric. Loquen: English Studies Journal, $13(1)$,

6-16. http://dx.doi.org/10.32678/loquen.v13i1.2548 
Eisend, M. (2019). Gender roles. Journal of Advertising, $48(1)$, $72-80$. https://doi.org/10.1080/00913367.2019.1566103

Fairclough, N. (1993). Critical discourse analysis and the marketization of a public discourse: The universities. Discourse \& Society SAGE, 4(2), 133-168. http://hjb.sagepub.com.proxy.lib.umich.edu/content/9 /2/183.full.pdf+html

Faizah, H. (2017). Linguistik umum. Cendikia Insani.

Hwai, G. (2018). "Diksi laki-laki dan perempuan" dalam puisi mutakhir Indonesia. Ilmu Sastra Dan Budaya, $4(2), 311-325$.

Keraf, G. (2010). Diksi dan gaya bahasa. Gramedia Pustaka Utama.

Kristi, P. (2019). Penguatan psikologis untuk menanggulangi kekerarasan dalam rumah tangga. $L B H$ APIK Jakarta.

Lakoff, R. (1975). Language and woman's place. Publishern Inc.

Leech, G. N. (1990). Semantics: The study of meaning. Penguin Books.

Lyons, J. (1995). Linguistic semantics: An introduction (1st ed.). Cambridge University Press.

McLeod, J. (2000). Beginning postcolonialism. Manchester University Press.

Oxford, D. (n.d.). Oxford advanced learner's dictionary online. https://www.oxfordlearnersdictionaries.com/

Palmer, F. R. (1976). Semantics: A new outline (2nd ed.). Cambridge University Press.

Pease, A., \& Pease, B. (2004). Why men don't listen and women can't read maps: How we're different and what to do about it. Great Britain: Orion Publishing Group.

Pilatova, A. (2015). The language of advertising: Analysis of advertising slogans in fast food industry. Masaryk University.

Prabasmoro, A. (2017). Becoming white: Representasi ras, kelas, feminitas, \& globalitas dalam iklan sabun. Jalasutra.

Pradopo, R. D. (2019). Stilistika kajian puitika bahasa, sastra, dan budaya. Pustaka Pelajar.

Saeed, J. I. (2003). Semantics (2nd ed.). Wiley.

Setiawati, D. (2018). Pemilihan Kata Dalam Iklan Kontak Jodoh. Laporan Penelitian. UI.

Stevenson, J., Campbell, K. L., Brown, M., Craig, J., \& ... (2019). Targeted, structured text messaging to improve dietary and lifestyle behaviours for people on maintenance haemodialysis (KIDNEYTEXT): study protocol for a .... In BMJ open. bmjopen.bmj.com. http://dx.doi.org/10.1136/bmjopen-2018-023545

Cucinotta, D., \& Vanelli, M. (2020). WHO declares COVID19 a pandemic. Acta Bio Medica: Atenei Parmensis, 91(1), 157.

Wulandari, Y. (2017). Associative meaning in the original slogan of fast food advertisement [Doctoral dissertation, Universitas Sumatera Utara]. UMSU Repository. http://repository.umsu.ac.id/handle/123456789/4072

Yananingtyas, H. Z. (2018). Functional semantic analysis on Nivea's printed advertisements [Doctoral dissertation, Universitas Islam Negeri Maulana Malik Ibrahim]. Etheses. http://etheses.uin-malang.ac.id/13221/

Yulianto. (2017). Pesona 'barat': Analisis kritis-historis tentang kesadaran warna kulit di Indonesia. Penerbit Jalasutra. 